Jurnal Keperawatan I CARE, Vol. 2 No. 1 Tahun 2021

\title{
FAKTOR YANG MEMPENGARUHI KEPATUHAN IBU HAMIL DALAM MELAKUKAN KUNJUNGAN ANTENATAL CARE (ANC) DI LAYANAN KESEHATAN
}

\author{
Ana Setiyorini ${ }^{1}$, Friska Yuliana Sijabat ${ }^{2}$, Maudy Anita Sari ${ }^{3}$
}

${ }^{1}$ STIKes Panti Rapih Yogyakarta, Jl. Tantular No. 401, Condongcatur, Depok, Sleman, Yogyakarta, email: setiyorini.ana@gmail.com

${ }^{2}$ STIKes Panti Rapih Yogyakarta, Jl. Tantular No. 401, Condongcatur, Depok, Sleman, Yogyakarta, email: friskayuliana02@gmail.com

${ }^{3}$ STIKes Panti Rapih Yogyakarta, Jl. Tantular No. 401, Condongcatur, Depok, Sleman, Yogyakarta, email: maudyans@gmail.com

\begin{abstract}
ABSTRAK
Latar Belakang: Antenatal care (ANC) adalah pelayanan kesehatan dari tenaga profesional pada ibu hamil sesuai dengan standar pelayanan yang diterapkan untuk meningkatkan kesehatan fisik dan mental pada ibu hamil secara optimal, hingga mampu menghadapi masa persalinan, nifas, menghadapi persiapan pemberian ASI secara eksklusif, serta kembalinya kesehatan alat reproduksi dengan wajar. Kepatuhan ibu dalam ANC dapat mendeteksi dan menangani masalah kehamilan yang berdampak pada kematian ibu. Pemanfaatan layanan kesehatan yang kurang dapat disebabkan oleh banyak faktor antara lain pengetahuan ibu hamil, jarak tempat tinggal, penghasilan keluarga, media informasi, dukungan keluarga, dan faktor petugas kesehatan.
\end{abstract}

Tujuan: Mengetahui faktor yang mempengaruhi kepatuhan ibu hamil dalam melakukan ANC di Rumah Sakit Panti Rini Yogyakarta.

Metode: Penelitian ini merupakan penelitian deskriptif analitik dengan rancangan cross sectional di Rumah Sakit Panti Rini Yogyakarta. Sampel dalam penelitian ini adalah 32 orang ibu hamil trimester 3 yang melakukan kunjungan pemeriksaan kehamilan yang diambil dalam kurun waktu 15 Desember 2020-6 Januari 2021 yang direkrut dengan tehnik accidental sampling. Analisis univariat, bivariat dengan uji statistik korelasi Spearman digunakan untuk mengetahui hubungan tiap variabel ( $p$-value) pada tingkat kemaknaan $p<0,05$.

Hasil : Faktor yang mempengaruhi kepatuhan ibu dalam melakukan ANC yaitu dukungan keluarga ( $p$-value $=0,000)$. Adapun faktor yang tidak mempengaruhi yaitu usia ibu ( $p$-value $=0,868)$, pendidikan ibu ( $p$-value $=0,644)$, Status pekerjaan ( $p$-value: 0,224$)$, pengetahuan ibu ( $p$-value: 0,175$)$, jarak tempat tinggal $(p$-value $=0,613)$, penghasilan keluarga $(p$-value $=0,921)$, media informasi $(p$-value $=0,233)$, dukungan petugas $(p$ value $=0,141)$.

Simpulan : Faktor yang mempengaruhi kepatuhan ibu dalam melakukan ANC yaitu dukungan keluarga. Faktor yang tidak mempengaruhi ibu dalam melakukan ANC yaitu usia, pendidikan ibu, status pekerjaan, pengetahuan ibu, jarak tempat tinggal, penghasilan keluarga, media informasi, dukungan petugas. Diharapkan keluarga tetap selalu mendukung ibu dalam memeriksakan kehamilan.

Kata Kunci: kepatuhan, antenatal care, faktor pengaruh 


\begin{abstract}
Background: Antenatal care (ANC) is a health service from professionals for pregnant women in accordance with service standards that implemented to improve the physical and mental health of pregnant women optimally, so that they able to face childbirth, postpartum periode, exclusive breastfeeding preparation, and periode of reproductive system return to its normal pre-pregnant stage. Mother's adherence in ANC attendance can detect and treat pregnancy problems which could impact on maternal mortality. Inadequate utilization of health services can be caused by many factors, including knowledge of pregnant women, distance of residence, family income, information from media, family support, and health workers' factor.
\end{abstract}

Objective: Determined the factors that influence the adherence of pregnant women to ANC attendance at Panti Rini Hospital Yogyakarta

Method: This research is a descriptive analytic study with a cross sectional design at Panti Rini Hospital Yogyakarta. The sample in this study were thirty-two of third trimester pregnant women who visited antenatal care during 15 December 2020-6 January 2021 which recruited with an accidental sampling. Univariate, bivariate analysis with the Spearman correlation statistical test used to determine the relationship of each variables ( $\mathrm{p}$-value) at the level of significance $p<0.05$.

Results: Factors that influence maternal adherence to ANC attendance were family support ( $\mathrm{p}$-value: 0,000 ). The factors that did not affect were maternal age (p-value: 0.868 ), maternal education ( $p$-value: 0.644$)$, employment status ( $p$-value: 0.224 ), maternal knowledge ( $p$-value: 0.175 ), distance of residence ( $p$-value: 0.613 ), family income ( $\mathrm{p}$-value: 0.921), media information ( $\mathrm{p}$-value: 0.233 ), support from officers ( $\mathrm{p}$-value: 0.141$)$.

Conclusions: Factors that influence maternal adherence to ANC attendance were family support. The factors that did not affect were maternal age, maternal education, employment status, maternal knowledge, distance of residence, family income, media information, support from officers. It is hoped that the family will always offer support the mother in checking her pregnancy.

Keywords: adherence, antenatal care, influencing factors

PENDAHULUAN

Antenatal care atau sering disebut dengan $A N C$ adalah pelayanan kesehatan dari tenaga

profesional pada ibu hamil sesuai

dengan standar pelayanan yang 
diterapkan untuk meningkatkan kesehatan fisik dan mental pada ibu hamil secara optimal, hingga mampu menghadapi masa persalinan, nifas, menghadapi persiapan pemberian ASI secara eksklusif, serta kembalinya kesehatan alat reproduksi dengan wajar (Sakinah dan Fibriana, 2015; Kemenkes, 2018). Menurut Alexander dan Hudayanti (2020), pemeriksaan kehamilan di negara berkembang cukup dilakukan 4 kali yaitu minimal 1 kali pada trimester pertama dan trimester kedua, dan minimal 2 kali pada trimester ketiga. Dari data Dinkes DIY, (2019), trend cakupan K4 dari 2014 sampai 2017 cenderung turun, namun ditahun 2018 cakupan K4 meningkat sedikit, Hal ini disebabkan karena belum semua ibu hamil mengakses layanan ANC sesuai waktu yang ditentukan (K1,K2,K3,K4). Rendahnya cakupan K1 dan K4 menyebabkan tidak terdeteksinya faktor resiko ibu hamil secara dini sehingga terlambat dalam penanganan yang dapat berakibat pada kematian ibu. Di Kabupaten Sleman, angka kematian ibu pada tahun 2018 mencapai 7, 2019 dan 2020 menjadi 8.00 (Bapedda
Yogyakarta, 2020). Faktor yang mempengaruhi kunjungan pemeriksaan kehamilan adalah sikap ibu hamil $(\mathrm{p}=0,001$, keterjangkauan layanan kesehatan $\quad(p=0,011)$ pengetahuan $(p=0,003)$, dukungan petugas kesehatan $(p=0,021)$ dan dukungan keluarga $(p=$ 0,022) (Erlina, R., dkk.,2013; Armaya, R., 2018). Dengan mengikuti ANC secara teratur diharapkan ibu hamil serta petugas kesehatan mampu mendeteksi serta menangani ketika terjadinya komplikasi, sehingga ANC sangat penting untuk menjamin bahwa proses alami dalam kehamilannya berjalan seperti standar dan dengan normal (Evayanti, 2015). Tujuan dari penelitian yang dilakukan adalah mengetahui hubungan faktor usia ibu, tingkat pendidikan, status pekerjaan, pengetahuan, jarak tempat tinggal, penghasilan, media informasi, dukungan keluarga, dukungan petugas kesehatan terhadap kepatuhan ibu hamil dalam melakukan pemeriksaan ANC di Rumah Sakit Panti Rini Yogyakarta.

\section{METODE PENELITIAN}

Penelitian ini merupakan penelitian deskriptif analitik dengan pendekatan cross sectional. Variabel 
penelitian ini adalah variabel bebas yaitu usia ibu, tingkat pendidikan, status pekerjaan, pengetahuan, jarak tempat tinggal, penghasilan, media informasi, dukungan keluarga, dukungan petugas kesehatan dan variabel terikat yaitu kepatuhan ibu hamil dalam melakukan pemeriksaan ANC.

Penelitian ini dilakukan di Rumah Sakit Panti Rini Yogyakarta denga pengambilan data pada Tanggal 15 Desember 2020-6 Januari 2021. Populasi dari penelitan ini adalah seluruh ibu hamil trimester 3 yang melakukan pemeriksaan ANC di Poli Kebidanan Rumah Sakit Panti Rini Yogyakarta. Sampel dalam penelitian ini diambil menggunakan teknik acidental sampling pada ibu hamil yang melakukan permeriksaan ANC dalam kurun waktu 15 Desember 2020-6 Januari 2021 sebanyak 32 pasien.

Pengumpulan data diawali dengan melakukan perijinan ke lokasi penelitian. Peneliti memilih responden sesuai dengan kriteria dan melakukan pengambilan data yang didahului dengan penjelasan alasan melakukan penelitian kepada responden sesuai dengan etika penelitian. Data diambil setelah responden menyatakan setuju sebagai sumber data yang dibuktikan dengan menandatangani lembar persetujuan menjadi responden. Peneliti mengambil data dengan cara memberikan surat permohonan menjadi responden, lembar persetujuan menjadi responden dan kemudian memberikan kuesioner yang harus diisi oleh responden. Responden menuliskan jawaban sesuai dengan petunjuk yang ada pada kuesioner. Setelah responden selesai mengisi kuesioner, peneliti mengecek kelengkapan data, lembar persetujuan menjadi responden yang telah ditandatangani. Peneliti melengkapi data dengan mengambil data yang ada di Medical Record Rumah Sakit Panti Rini Yogyakarta.

Instrumen penelitian dibuat oleh peneliti berdasarkan tujuan penelitian. Instrumen yang digunakan adalah kuesioner yang mencakup semua variabel yang diukur. Kuesioner terdiri dari 38 pernyataan dan pertanyaan yang dengan rincian kepatuhan ibu hamil 4 pernyataan, usia 1 pertanyaan, tingkat pendidikan 1 pertanyaan, status pekerjaan 1 pertanyaan, pengetahuan ibu hamil 10 pernyataan, jarak tempat 
tinggal 1 pertanyaan, penghasilan keluarga 1 pertanyaan, media informasi 5 pernyataan, dukungan keluarga 5 pernyataan, faktor petugas kesehatan 5 pernyataan yang disusun berupa pilihan mencentang antara Ya dan Tidak serta Benar dan Salah.

Pengolahan data dilakukan dengan proses editing, coding, scoring, dan tabulating. Analisis data dilakukan secara kuantitatif dan disesuaikan dengan tujuan yang akan dicapai pada penelitian ini dengan distribusi frekuensi yang ditampilkan dalam bentuk narasi dan tabel. Data hasil penghitungan distribusi frekuensi dan hasil prosentase dari variabel disajikan dalam bentuk narasi dengan kategori 0\%: Tidak ada, 1-25\%: Sebagian kecil, 26-49\%:
75\%: Lebih dari separo, 76-99\%: Sebagian besar, dan 100\%: Seluruhnya. Analisa bivariat dilakukan untuk menguji hubungan antara variabel bebas dan variabel terikat menggunakan analisis korelasi Spearman guna mengetahui p-value dengan signifikansi hubungan $p<0,005$.

\section{HASIL DAN PEMBAHASAN}

Penelitian tentang faktor yang mempengaruhi kepatuhan ibu hamil dalam melakukan pemeriksaan ANC merupakan penelitian deskriptif kuantitatif dengan pendekatan cross sectional yang dilakukan di Rumah Sakit Panti Rini Yogyakarta dengan menggunakan data primer.

Kurang dari separo, 50\%: Separo, 51-

Tabel 1

Hubungan Antara Variabel Kepatuhan Ibu Dalam Melakukan Pemeriksaan ANC

Dengan Variabel

\begin{tabular}{|c|c|c|c|c|c|c|c|}
\hline \multirow{4}{*}{ Variabel } & \multicolumn{4}{|c|}{$\begin{array}{c}\text { Kepatuhan Melakukan Pemeriksaan } \\
\text { ANC }\end{array}$} & \multicolumn{2}{|c|}{ Total } & \multirow{4}{*}{$\begin{array}{c}p- \\
\text { value }\end{array}$} \\
\hline & \multirow{2}{*}{\multicolumn{2}{|c|}{$\begin{array}{c}\text { Tidak Patuh } \\
(\mathbf{n}=\mathbf{1 0})\end{array}$}} & \multirow{2}{*}{\multicolumn{2}{|c|}{$\begin{array}{l}\text { Patuh } \\
(n=22)\end{array}$}} & \multirow{2}{*}{\multicolumn{2}{|c|}{$(n=32$}} & \\
\hline & & & & & & & \\
\hline & $\mathbf{N}$ & $(\%)$ & $\mathbf{N}$ & $(\%)$ & $\mathbf{N}$ & $\%$ & \\
\hline Usia Responden & & & & & & & 0,868 \\
\hline Dibawah 20 tahun & 0 & 0 & 0 & 0 & 0 & 0 & \\
\hline 20-35 tahun & 8 & 80 & 17 & 77,3 & 25 & 78,1 & \\
\hline Diatas 35 tahun & 2 & 20 & 5 & 22,7 & 7 & 21,9 & \\
\hline Total & 10 & $(100)$ & 22 & $(100)$ & 32 & $(100)$ & \\
\hline Tingkat Pendidikan & & & & & & & 0,644 \\
\hline Dasar & 0 & 0 & 0 & 0 & 0 & 0 & \\
\hline Menengah & 5 & 50 & 13 & 59 & 18 & 56,3 & \\
\hline Tinggi & 5 & 50 & 9 & 41 & 14 & 43,7 & \\
\hline Total & 10 & $(100)$ & 22 & $(100)$ & 32 & $(100)$ & \\
\hline
\end{tabular}


Ana Setiyorini, Friska Yuliana Sijabat, Maudy Anita Sari Faktor yang Mempengaruhi Kepatuhan Ibu Hamil

Dalam Melakukan Kunjungan Antenatal Care (ANC) di Layanan Kesehatan

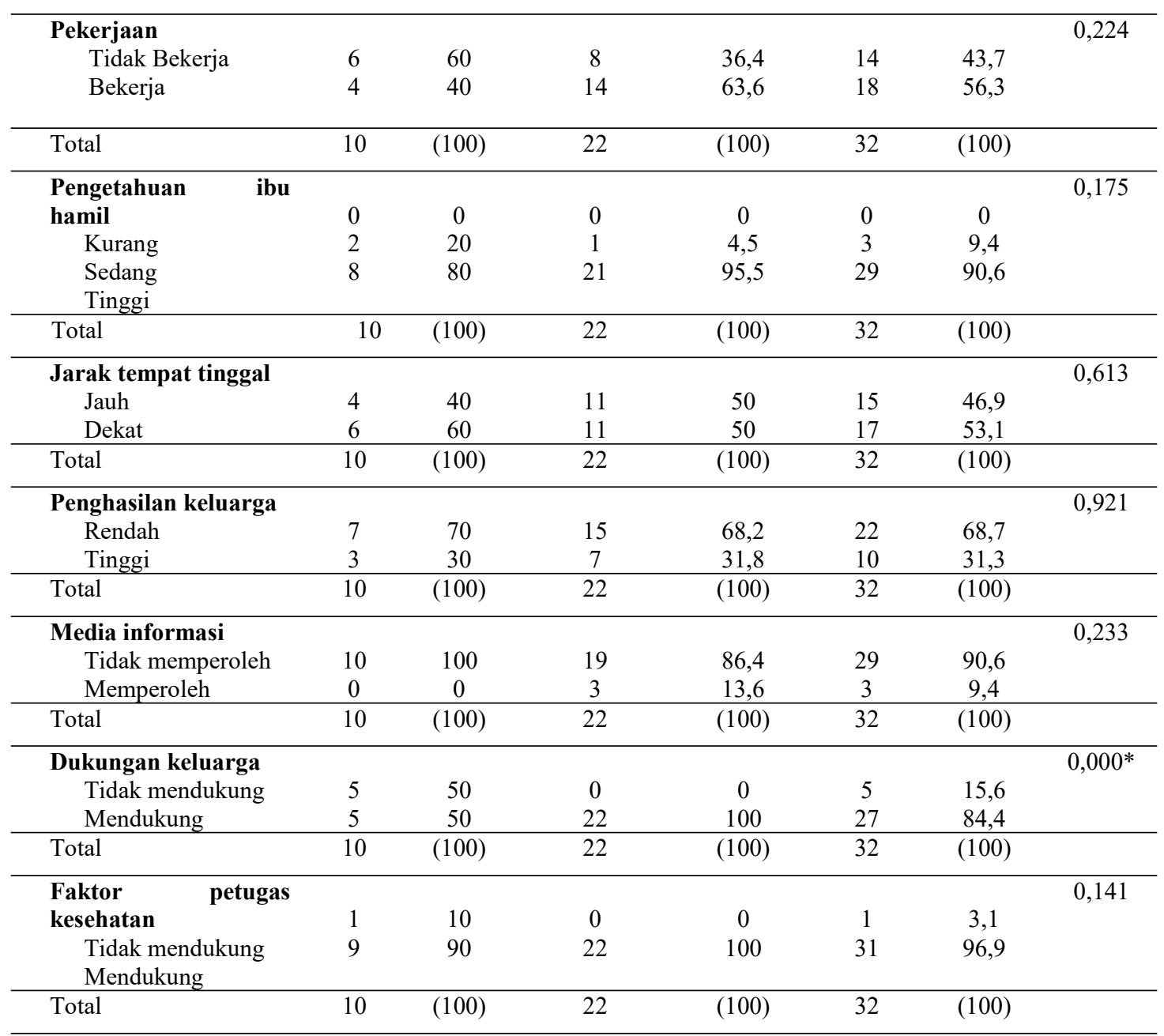

Keterangan: *: p-value $<0,05$ (signifikan)

Berdasarkan tabel 1, hasil dengan layanan kesehatan, terdapat 22 penelitian yang terdiri dari $32(68,7 \%)$ atau lebih dari separoh responden, terdapat $25(78,1 \%)$ atau berpenghasilan rendah, terdapat 29 sebagian besar berusia $20-35$ tahun, $(90,6 \%)$ atau sebagian besar tidak terdapat $18(56,3 \%)$ atau lebih dari memperoleh informasi, terdapat 27 separoh mempunyai tingkat $(84,4 \%)$ atau sebagian besar pendidikan menengah, terdapat 18 mendapatkan dukungan keluarga dan $(56,3 \%)$ atau lebih dari separoh terdapat $31 \quad(96,9 \%)$ atau sebagian bekerja, terdapat $29(90,6 \%)$ atau besar mendapat dukungan dari petugas sebagian besar berpengetahuan tinggi, kesehatan.

terdapat $17(53,1 \%)$ atau lebih dari separoh mempunyai jarak yang dekat

Dari hasil analisis didapatkan tidak ada hubungan yang signifikan 
antara usia ibu dengan kepatuhan ibu hamil dalam melakukan pemeriksaan ANC ( $p$-value: 0,868$)$. Hal ini sejalan dengan penelitian Sari, dkk. (2018) dengan p-value 0,514 . Usia merupakan faktor yang mempengaruhi perilaku termasuk perilaku dalam melakukan pemeriksaan kehamilan. Namun demikian dari data penelitian ini tidak ada hubungan, maka peneliti berasumsi bahwa hal ini disebabkan karena sebagian besar $(78,1 \%)$ responden terdapat pada rentang usia produktif dan sudah melakukan pemeriksaan kehamilan.

Dari hasil analisis didapatkan tidak ada hubungan yang signifikan antara tingkat pendidikan dengan kepatuhan ibu hamil dalam melakukan pemeriksaan ANC ( $p$ value: 0,664). Hal ini sejalan dengan penelitian Sari, dkk. (2018) dengan $p$ value 1,000; Gamelia, dkk . (2013) dengan $\quad p$-value 0,566 ; Wuryani dan Aisyah (2019) dengan p-value 0,094 . Secara umum pendidikan yang tinggi akan mempengaruhi perilaku. Pendidikan tinggi yang dimiliki oleh ibu merupakan faktor penting yang melatarbelakangi dan memotivasi ibu hamil untuk melakukan pemeriksaan kehamilan secara teratur. Namun demikian, bukan berarti bahwa ibu hamil dengan latar belakang pendidikan rendah tidak melakukan pemeriksaan kehamilan sesuai standar. Analisis peneliti terhadap ketidakada hubungan mungkin karena responden tidak ada yang berpendidikan rendah.

Dari hasil analisis didapatkan tidak ada hubungan yang signifikan antara status pekerjaan dengan kepatuhan ibu hamil dalam melakukan pemeriksaan ANC (p-value: 0,224). Hal ini sejalan dengan penelitian Sari, dkk. (2018) dengan p-value 0,596; Gamelia, dkk (2013) dengan p-value 0,695; Wuryani dan Aisyah (2019) dengan $p$-value 0,257. Pekerjaan menunjang kemampuan ibu hamil tersebut untuk dapat memeriksakan kehamilannya baik dalam segi biaya maupun waktu, namun demikian bagi ibu yang tidak bekerja mestinya juga mempunyai kesempatan yang lebih besar dalam melakukan pemeriksaan. Dengan demikian dapat dikatakan bahwa bekerja atau tidak bekerja mempunyai peluang yang sama untuk melakukan pemeriksaan kehamilan 
yang tetntunya dapat dipengaruhi oleh faktor lain seperti dukungan keluarga, biaya dan waktu.

Dari hasil analisis didapatkan tidak ada hubungan yang signifikan antara pengetahuan dengan kepatuhan ibu hamil dalam melakukan pemeriksaan ANC (p-value: 0,175). Hal ini tidak sejalan dengan penelitian Armaya (2018) dengan p-value 0,003; Sari, M.M, dkk (2018) dengan $p$ value 0,019; Ha, B.TT., et. al. (2015) dengan p-value 0,000 . Namun penelitian ini sejalan dengan penelitian Erlina, dkk (2013) dengan p-value 0,515; Gamelia, dkk (2013) dengan p-value 0,412; Alexander dan Hudayanti (2020) dengan p-value 0,05 . Menurut peneliti, semakin pengetahuan tinggi akan semakin membuat orang melakukan sesuatu yang baik, implementasinya jika pengetahuan ibu tinggi maka akan melakukan pemeriksaan kesehatan. Dalam penelitian ini, peneliti berasumsi bahwa tidak ada hubungan karena sebagian besar $(90,6 \%)$ resonden mempunyai pendidikan yang tinggi.

Dari hasil analisis didapatkan tidak ada hubungan yang signifikan antara jarak tempat tinggal dengan kepatuhan ibu hamil dalam melakukan pemeriksaan ANC (p-value: 0,613). Hal ini sejalan dengan penelitan Sari, dkk (2018) dengan p-value 0,670; Wuryani dan Aisyah (2019) dengan $p$ value 0,716 . Namun tidak sejalan dengan penelitian Ha, B.TT., et. al. (2015) dengan p-value 0,023. Jarak tempat tinggal berhubungan dengan waktu tempuh dan biaya. Tempat pelayanan yang lokasinya tidak strategis atau sulit dicapai oleh para ibu menyebabkan berkurangnya akses ibu hamil terhadap pelayanan kesehatan. Meskipun ketersediaan pelayanan kesehatan sudah memadai, namun penggunaannya tergantung dari aksesibilitas masyarakat terhadap informasi.

Dari hasil analisis didapatkan tidak ada hubungan yang signifikan antara penghasilan keluarga dengan kepatuhan ibu hamil dalam melakukan pemeriksaan ANC (p-value: 0,921). Hal ini sejalan dengan pelitian Sari, dkk (2018) dengan p-value 1,000; Gamelia, dkk (2013) dengan p-value 0,205. Namun tidak sejalan dengan penilitian Ha, B.TT., et. al. (2015) dengan p-value 0,000. Ibu dengan penghasilan yang rendah dapat dikaitkan dengan pendidikan yang 
rendah sehingga tidak bekerja. pandemi Covid-19 sehingga lebih Menurut peneliti, dalam penelitian ini walaupun lebih dari separoh $(68,7 \%)$ responden berpenghasilan rendah namun tetap melakukan pemeriksaan kehamilan karena didukung oleh faktor lain yaitu dukungan keluarga.

Dari hasil analisis didapatkan tidak ada hubungan yang signifikan antara memperoleh media informasi dengan kepatuhan ibu hamil dalam melakukan pemeriksaan ANC ( $p$ value: 0,233). Hal ini sejalan dengan penelitian Sari, dkk (2018) dengan $p$ value 0,076. Namun tidak sejalan dengan penelitian Rwabilimbo, et. al. (2020) yang menyatakan bahwa media informasi yang diakses dapat memberikan gambaran tentang pentingnya layanan kesehatan dan meningkatkan pemanfaatan layanan kesehatan. Menurut peneliti, media informasi yang berisi tentang pentingnya pelayanan ANC dapat meningkatkan pengetahuan serta memotivasi ibu hamil untuk melakukan pemeriksaan, namun demikian penelitian ini tidak ada hubungan karena sebagian besar (90,6\%) tidak memperoleh informasi yang mungkin disebabkan masa banyak memperoleh informasi yang tidak terkait dengan kehamilannya.

Dari hasil analisis didapatkan ada hubungan yang signifikan antara dukungan keluarga dengan kepatuhan ibu hamil dalam melakukan pemeriksaan ANC (p-value: 0,000). Hal ini sejalan dengan hasil penelitian Armaya (2018) dengan p-value 0,022. Keluarga merupakan lingkungan yang terdekat dengan ibu hamil, setelah suami. Dukungan dari keluarga sangat mempengaruhi ibu secara psikologi bahwa ia merasa diterima. Kenyamanan psikis maupun emosional yang diterima individu dari dukungan keluarga akan dapat melindungi individu dari konsekuensi stress dan termotivasi untuk melakukan pemeriksaan kesehatan.

Dari hasil analisis didapatkan tidak ada hubungan yang signifikan antara dukungan petugas dengan kepatuhan ibu hamil dalam melakukan pemeriksaan ANC (p-value: 0,141). Hal ini tidak sejalan dengan hasil penelitian Armaya (2018) dengan $p$ value 0,021. Namun sejalan dengan penelitian Gamelia, dkk (2013) dengan p-value 0,218. Bantuan 
dari petugas sangatlah berarti terhadap ibu yang hamil, terutama yang belum mempunyai pengalaman. Dari hasil penelitian tidak ada hubungan antara dukungan petugas dengan kepatuhan pemeriksaan kehamilan, peneliti berasumsi bahwa sebagian besar $(96,9 \%)$ ibu yang memeriksakan kehamilan sudah mendapat dukungan dari petugas.

\section{KESIMPULAN DAN SARAN}

\section{Kesimpulan}

Berdasarkan hasil penelitian dan pembahasan yang telah diuraikan dapat disimpulkan sebagai berikut:

1. Faktor yang mempengaruhi kepatuhan ibu dalam melakukan pemeriksaan ANC yaitu dukungan keluarga

2. Faktor tidak yang mempengaruhi kepatuhan ibu dalam melakukan pemeriksaan ANC yaitu usia ibu, pendidikan ibu, status, pengetahuan ibu, jarak tempat tinggal, penghasilan keluarga, media informasi, dukungan petugas.

\section{Saran}

1. Bagi petugas kesehatan Poli Kebidanan RS Panti Rini
Tetap mempertahankan dukungan kepada ibu hamil untuk tetap melakukan pemeriksaan kehamilan secara teratur sesuai standar

2. Bagi keluarga ibu hamil

Tetap selalu mendukung ibu dalam memeriksakan kehamilan baik dalam biaya, akses ke layanan kesehatan, mencarikan informasi, serta mengantarkan ibu untuk periksa ke layanan kesehatan.

\section{DAFTAR PUSTAKA}

Alexander dan Hudayanti, N. (2020). Hubungan pengetahuan tentang pemeriksaan kehamilan dengan kepatuhan kunjungan antenatal care di Puskesmas Wajok Hulu Kecamatan Siantan Kabupaten Mempawah Tahun 2019. Jurnal Kebidanan.Vol 10 No. 2. PISSN 2252-8121, e-ISSB 26204894. Hal 540-546. https://doi.org/10.33486/123akp b.v10i2.101

Armaya, R. (2018). Kepatuhan ibu hamil dalam melakukan kunjungan antenatal care dan faktor yang mempengaruhi. Jurnal Ilmu Kesehatan Masyarakat. Vol 7 No 01. eISSN 2354-8185 (online), p- 
ISSN 2252-4134. Hal 43-50.

Sekolah Tinggi Ilmu

Kesehatan Indonesia Maju,

Jakarta

Bapedda Yogyakarta (2020).

Pertumbuhan penduduk.

Bapedda Yogyakarta.

http://bappeda.jogjaprov.go.id/

dataku/data_dasar?id_skpd $=29$

\#15

Dikes DIY. (2019). Profil Kesehatan

2019. (Data tahun 2018).

https://kesehatan.jogjakota.go.

id

Erlina, R., Larasati, TA., Kurniawan,

B. (2013). Faktor-faktor yang mempengaruhi ibu hamil terhadap kunjungan pemeriksaan kehamilan di Puskesmas Rawat Inap Panjang Bandar Lampung. Medical Journal of Lampung University. Volume 2 No 4. ISSN 2337-3776, E ISSN 2599-0527. Hal 29-34

Evayanti, Y. (2015). Hubungan pengetahuan ibu dan dukungan suami pada ibu hamil terhadap keteraturan kunjungan antenatal care (ANC) di Puskesmas Wates
Lampung Tengah Tahun 2014. Jurnal Kebidanan Vol 1, No 2, Hal 81-90

Gamelia, E., Sistiarani, C., Masfiah, S. (2013) Determinan Perilaku Perawatan Kehamilan. Jurnal Kesehatan Masyarakat Nasional Vol. 8, No. 3. p-ISSN: 19077505, e-ISSN: 2460-0601. Hal 109-114. Jurusan Kesehatan Masyarakat Fakultas Kedokteran dan Ilmu-ilmu Kesehatan. Universitas Jenderal Soedirman

Ha, B.TT., Tac, P.V., Duc, D.M., Duong, D.TT., and Thi, L.M. (2015). Factors associated with four or more antenatal care services among pregnant women: a cross-sectional survey in eight south central coast provinces of Vietnam. International Journal of Women's Health. Hal 699-706

Kemenkes. (2018). Pentingnya Pemeriksaan Kehamilan (ANC) di Fasilitas Kesehatan. https://promkes.kemkes.go.id/

Rwabilimbo, A.G., Ahmed, K.Y., Page, A., and Ogbo, F.A. (2020) Trends and factors associated 
with the utilisation of

antenatal care services during

the Millennium Development

Goals era in Tanzania.

Tropical Medicine and Health.

48:38. Page 1-16

Sakinah, V., \& Fibriana, A. (2015). Upaya peningkatan pengetahuan, sikap dan kunjungan antenatal care (ANC) ibu hamil melalui pemberdayaan kader ANC. Unnes Journal of Public Health, 4(1). https://doi.org/10.15294/ujph. v4i1.4710

Sari, M.M., Nurkamila, N., dan Mawati, E.D. (2018). Faktorfaktor yang mempengaruhi kepatuhan ibu hamil dalam

melakukan pemeriksaan

kehamilan di Puskesmas

Cibungbulang Kabupaten

Bogor Provinsi Jawa Barat

Tahun 2018. PROMOTOR

Jurnal Mahasiswa Kesehatan Masyarakat. Vol. 1 No. 2. ISSN 2654-7899, E ISSN 2654-8127.

Hal 96-104. Universitas Ibn Khaldun Bogor

Wuryani, M. dan Aisyah. (2019). Analisa determinan yang berhubungan dengan kunjungan pemeriksaan kehamilan (K4). Jurnal SMART Kebidanan. Vol. 5 No. 2. ISSN:2503-0388. Hal 18-27. Sekolah Tinggi Ilmu Kesehatan (STIKes) Karya Husada Semarang 